OPEN ACCESS

Edited by:

Qi Yuan,

Memorial University of Newfoundland,

Canada

Reviewed by:

Nathan Schoppa,

University of Colorado Denver School

of Medicine, United States

Graeme Lowe

Monell Chemical Senses Center,

United States

*Correspondence: Hong-Wei Dong

hongwei.dong@vanderbilt.edu

Received: 26 September 2017 Accepted: 29 December 2017

Published: 17 January 2018

Citation:

Dong H-W and Ennis M (2018) Activation of Group II Metabotropic

Glutamate Receptors Suppresses Excitability of Mouse Main Olfactory

Bulb External Tufted and Mitral Cells.

Front. Cell. Neurosci. 11:436

doi: 10.3389/fncel.2017.00436

\section{Activation of Group II Metabotropic Glutamate Receptors Suppresses Excitability of Mouse Main Olfactory Bulb External Tufted and Mitral Cells}

\author{
Hong-Wei Dong * and Matthew Ennis \\ Department of Anatomy and Neurobiology, University of Tennessee Health Science Center, Memphis, TN, United States
}

Metabotropic glutamate receptors (mGluRs) are abundantly expressed in the rodent main olfactory bulb. The function of Group I mGluRs has been investigated in a number of studies, while the actions of Group II mGluRs, which include the mGluR2 and mGluR3 subtypes, have been less well explored. Here, we used electrophysiological approaches in mouse olfactory bulb slices to investigate how Group II mGluR activation and inactivation modifies the activity of external tufted (ET) and mitral cells. The Group II mGluR agonist DCG-IV was found to directly and uniformly reduce the spontaneous discharge of ET and mitral cells. The inhibitory effect of DCG-IV was absent in mitral cells with truncated apical dendrites, indicating a glomerular site of action. DCG-IV did not influence olfactory nerve-evoked monosynaptic responses in ET or mitral cells, indicating that Group II mGluRs do not presynaptically modulate glutamate release from olfactory nerve terminals. In contrast, DCG-IV suppressed polysynaptic responses in periglomerular cells evoked by olfactory nerve stimulation. DCG-IV also inhibited glutamate release from ET cells, and suppressed the spontaneous and olfactory nerveevoked long-lasting depolarization in mitral cells. Applied alone, Group II receptor antagonists were without effect, suggesting that basal activation of these receptors is nil. These findings suggest that Group II mGluRs inhibit ET and mitral cell activity and further dampen intraglomerular excitatory circuits by suppressing glutamate release.

Keywords: mGluRs, mGluR2, external tufted cell, mitral cell, glomerulus, mouse main olfactory bulb

\section{INTRODUCTION}

Neurons in main olfactory bulb (MOB) express members of the three-metabotropic glutamate receptor (mGluR) family groups designated as: Group I (mGluR1 and 5), Group II (mGluR2 and 3) and Group III (mGluR4 and 6-8) (Conn and Pin, 1997). The function of Group I mGluRs (mGluR1 and 5) in the MOB has been explored in a number of studies and has been linked to excitation of mitral/tufted and granule cells, slow oscillatory activity in response to olfactory nerve input and prolonged odor responses (Schoppa and Westbrook, 2001; Heinbockel et al., 2004, 2007; Yuan and Knopfel, 2006; Dong et al., 2007, 2009; Matsumoto et al., 2009).

Group II mGluRs in the MOB have been less explored. Anatomically, mGluR3 mRNA expression is negligible in the $\mathrm{MOB}$, with only few scattered neurons of unknown identity observed (Ohishi et al., 1993). mGluR2 protein or mRNA localization studies report the presence of labeled neuron in all MOB layers, with substantial populations in the glomerular, mitral and granule cell 
layers (Ohishi et al., 1993, 1998). Labeled neurons were not definitively identified however, and the intense neuropil staining with mGluR2 immunocytochemistry in these and other studies (Neki et al., 1996) made cellular expression difficult. Studies using nonspecific mGluR2/3 antibodies (Petralia et al., 1996; Sahara et al., 2001) yielded results comparable to mGluR2 specific antibodies, suggesting that mGluR2 is the only Group II receptor with a significant functional role in the MOB.

Although Group II mGluRs play a well characterized disinhibitory role in the accessory olfactory bulb where they suppress GABA release at granule-to-mitral cell dendrodendritic synapses (Hayashi et al., 1993), relatively little is known about their function in the MOB. A recent study indicates mGluR2 acts similarly in the MOB to suppress GABA release from granule and periglomerular (PG) cells (Zak et al., 2015). The impact of Group II mGluRs on other elements of the MOB circuitry remain unexplored. The present study therefore investigated the actions of Group II mGluR activation and inactivation on external tufted (ET) and mitral cells using electrophysiological approaches in mouse MOB slices. Our findings indicate that Group II mGluR activation suppresses the excitability of both cell types.

\section{MATERIALS AND METHODS}

\section{Slice Preparation}

Male and female 21-42 day old C57BL/6J mice were obtained from Jackson laboratory. All animals were housed in a vivarium that was maintained between 22 and $23^{\circ} \mathrm{C}$ and under a $12-\mathrm{h}$ light on/off cycle. Food and water were available ad libitum. All experimental procedures described below were reviewed and approved by Institutional Animal Care and Use Committee of University of Tennessee Health Science Center in accordance with and National Institutes of Health guidelines. Mice were decapitated and horizontal $400 \mu \mathrm{m}$-thick olfactory bulb slices were prepared as previously described (Dong and Ennis, 2014). Briefly, the olfactory bulbs were removed and immersed in oxygenated chilled sucrose-artificial cerebrospinal fluid (ACSF) composed of the following (in $\mathrm{mM}$ ): $62 \mathrm{NaCl}, 26 \mathrm{NaHCO}_{3}$, $1.25 \mathrm{NaH}_{2} \mathrm{PO}_{4}, 3 \mathrm{KCl}, 4 \mathrm{MgSO}_{4}, 0.1 \mathrm{CaCl}_{2}, 15$ glucose, and 120 sucrose; pH 7.3, 310 mOsm. Horizontal slices were cut with a vibrating microtome (Leica VT 1200S, Leica, Germany) at thickness of $400 \mu \mathrm{m}$. After recovery at $33^{\circ} \mathrm{C}$ for $20 \mathrm{~min}$, slices were incubated until used at room temperature $\left(22^{\circ} \mathrm{C}\right)$ in normal ACSF equilibrated with carbogen $\left(95 \% \mathrm{O}_{2}-5 \% \mathrm{CO}_{2}\right)$ and composed of the following (in $\mathrm{mm}$ ): $126 \mathrm{NaCl}, 26 \mathrm{NaHCO}_{3}$, $3 \mathrm{KCl}, 1.25 \mathrm{NaH}_{2} \mathrm{PO}_{4}, 2 \mathrm{MgCl}_{2}, 2 \mathrm{CaCl}_{2}$, and 15 glucose $(\mathrm{pH}$ $7.3,310 \mathrm{mOsm}$ ). For recording, a single slice was placed in a recording chamber and continuously perfused with carbogensaturated ACSF at the rate of $1.5-2 \mathrm{ml} / \mathrm{min}$. On average, it took $\sim 1.5 \mathrm{~min}$ for drugs to arrive at the recording chamber and $\sim 3$ min to achieve stable effects.

\section{Electrophysiology}

Recordings were performed at $30^{\circ} \mathrm{C}$. Neurons were visualized using an upright microscope (BX50 WI; Olympus, Tokyo, Japan) equipped with epifluorescence and near-infrared differential interference contrast optics. Patch pipettes were fabricated from borosilicate glass and were pulled to a resistance of 3-5 M $\Omega$ for mitral cells, 5-7 M $\Omega$ for ET cells, and 7-9 $\mathrm{M} \Omega$ for PG cells. Only neurons with access resistance less than $25 \mathrm{M} \Omega$ were included in this study. Unless otherwise noted, the intracellular solution for both voltage and currentclamp recordings was composed of (in $\mathrm{mM}$ ): 124 potassium gluconate, $1 \mathrm{NaCl}, 10$ phosphocreatine di(tris) salt, $3 \mathrm{MgATP}$, $0.3 \mathrm{Na}_{2}$ GTP, 0.5 EGTA, and 10 HEPES; pH 7.3, $290 \mathrm{mOsm}$. The internal solution for self-excitation experiments was (in $\mathrm{mM}): 125$ cesium methanesulfonate $\left(\mathrm{CsMeSO}_{3}\right), 1 \mathrm{NaCl}, 10$ phosphocreatine di(tris) salt, $3 \mathrm{MgATP}, 0.3 \mathrm{Na}_{2} \mathrm{GTP}, 0.5$ EGTA, 10 HEPES; pH 7.3, 290 mOsm. Extracellular recordings were obtained using patch pipettes filled with ACSF.

Cells recorded in whole cell mode were filled with Lucifer yellow $(0.02 \%)$ for in situ determination of location and morphology. Recorded cells were identified by location, morphology and electrophysiological properties (Hayar et al., 2004a,b, 2005; Hayar and Ennis, 2007; Liu and Shipley, 2008a,b; Dong et al., 2009; Dong and Ennis, 2014). Briefly, ET cells were distinguished by (1) a relatively large soma and a primary dendrite with a tuft-like arborization that ramifies within a single glomerulus, (2) lack of secondary dendrites, and (3) distinct spontaneous rhythmic bursting. PG cells were identified by: (1) relatively small soma and a restricted dendritic arbor, (2) relatively high input impedance $(\sim 1,000 \mathrm{M} \Omega)$ compared to ET or mitral cells, and (3) spontaneous bursts of EPSPs or EPSCs. Mitral cells were identified by large soma in the mitral cell layer and an apical dendrite that arborized in a single glomerulus.

Whole cell voltage- or current-clamp recordings were made with a MultipleClamp 700B amplifier (Molecular Devices, Sunnyvale, CA). The junction potential was $9-10 \mathrm{mV}$, and all reported voltage measurements were uncorrected for these potentials. No series resistance compensation was performed. Analog signals were low-pass filtered at $2 \mathrm{kHz}$ (MultiClamp 700B) and digitized at $5 \mathrm{kHz}$ using a Digidata 1,440 A interface and pClamp 10.3 software (Molecular Devices). Miniature EPSCs (mEPSCs) were isolated by bath application of (in $\mu \mathrm{M}): 10$ gabazine, 50 APV, 1 TTX. Robust self-excitation was evoked in ET cells by a brief depolarizing step $(-60$ to $0 \mathrm{mV}, 5 \mathrm{~ms})$ in normal ACSF with glutamate $(10 \mu \mathrm{M})$ in the internal solution to avoid transmitter depletion (Ma and Lowe, 2007; De Saint Jan et al., 2009). Olfactory nerve (ON) stimulation $(0.1 \mathrm{~Hz}, 100 \mu \mathrm{s}$ in duration, 15-40 $\mu \mathrm{A}$ intensity) was via a bipolar concentric stainless steel electrode $(25 \mu \mathrm{m}$ in diameter) placed in the $\mathrm{ON}$ layer. Isolated constant current pulses from an ISO-Flex isolator (AMPI) were controlled by a Master- 8 stimulator. Spontaneous EPSCs (sEPSCs) were recorded at a holding potential of $-60 \mathrm{mV}$. EPSC bursts in PG cells were defined as a series of four or more consecutive sEPSC occurring at less than $30 \mathrm{~ms}$ intervals. A spike burst in ET cells was defined as a series of two or more consecutive spikes occurring at $<75 \mathrm{~ms}$ intervals (Dong et al., 2009). Detection of EPSCs, spikes and LLDs was performed offline using Mini Analysis program (Synaptosoft, Decature, GA). All detected events were visually confirmed. To measure steadystate membrane potential during spontaneous spiking, traces were low pass filtered at $5 \mathrm{~Hz}$ and the membrane potential was averaged in a $30 \mathrm{~s}$ epoch. Data were expressed as mean \pm SEM 
and statistically analyzed with paired or unpaired $t$-tests unless noted otherwise.

\section{Drugs and Solutions}

Unless otherwise noted, drugs and solutions were applied to the perfusion solution with a three-way valve system. Recording media, gabazine, 6-cyano-7-nitroquinoxaline-2,3dione (CNQX), $( \pm$ ) 2-amino-5-phosphonopentanoic acid (APV) were obtained from Sigma-Aldrich (St. Louis, MO). 3, 4-dihydroxyphenylglycine (DHPG), 2', 3'-dicarboxycyclopropyl glycine (DCG-IV), LY341495, tetrodotoxin (TTX) were purchased from Tocris Bioscience (Ellisville, MO).

\section{RESULTS}

\section{Activation of Group II mGluRs Suppresses ET Cell Bursting}

Previous studies reported that activation of group I mGluRs with DHPG or the mixed group I/II/III mGluR agonist L-CCG-I directly increased ET cell rhythmic bursting (Ishida et al., 1993; Tomita et al., 2000; Kirschstein et al., 2004; Dong et al., 2009). Here, we examined if selective activation of group II mGluRs with the agonist DCG-IV (Salin et al., 2001; Taniguchi et al., 2013; Zak et al., 2015) modulated ET cell spontaneous bursting. Extracellular recordings were used to obviate burst rundown in ET cells that can occur during whole cell recordings. Bath applied DCG-IV $(2 \mu \mathrm{M})$ significantly dampened ET cell firing properties ( $n=6$, Figures 1A,D), decreasing burst frequency by $44.3 \pm$ $8.3 \%(2.6 \pm 0.5 \mathrm{~Hz}$ to $1.6 \pm 0.4 \mathrm{~Hz}, p<0.01$, paired $t$-test $)$ and the mean firing frequency by $29.6 \pm 7.6 \%(8.5 \pm 2.0$ to $6.4 \pm$ $1.8 \mathrm{~Hz}, p<0.05)$, while increasing number of spikes/burst by $32.4 \pm 10.6 \%$ ( $2.9 \pm 0.3$ to $4.0 \pm 0.6, p<0.05)$. Similar effects of DCG-IV were observed in the presence of CNQX $(10 \mu \mathrm{M})$, APV $(50 \mu \mathrm{M})$ and gabazine $(10 \mu \mathrm{M}), n=6$ (Figures 1B,D). Burst frequency decreased by $30.5 \pm 7.3 \%(2.5 \pm 0.6 \mathrm{~Hz}$ vs. $1.9 \pm$ $0.7 \mathrm{~Hz}, p<0.05$ paired $t$-test), firing frequency decreased by $24.1 \pm 6.0 \%(8.0 \pm 1.8 \mathrm{~Hz}$ vs. $6.3 \pm 1.7 \mathrm{~Hz}, p<0.05$ paired $t$-test); the number spikes/burst were unaffected $(3.3 \pm 0.3$ vs. $3.2 \pm 0.4, p>0.05)$. In the presence of CNQX-APV-gabazine and LY341495 $(2 \mu \mathrm{M})$, a selective Group II mGluR antagonist at low micromolar concentrations (Kingston et al., 1998), DCG-IV did not alter firing rate, burst rate or the number of spikes/burst (Figure 1C, D $p>0.05, n=4$, paired $t$-tests). These results show that activation of Group II mGluRs suppresses ET cell firing and this persists when ionotropic glutamate and GABA receptors are blocked (Figure 1D, $p>0.05$ for all firing parameters, Kruskal-Willis Test followed by Chi-Square post-hoc tests). The latter observation suggests that the suppression of firing is due primarily to a direct action on ET cells. This result was also verified in current clamp recordings, where DCG-IV $(2 \mu \mathrm{M})$ hyperpolarized ET cell membrane potential by $-2.4 \pm 0.6 \mathrm{mV}$ ( $p<0.05$, paired $t$-test, $n=5$, data not shown).

In order to assess the specificity of mGluR actions, we investigated if Group II mGluRs presynaptically influence glutamate release from $\mathrm{ON}$ terminals. We first examined if DCG-IV influences monosynaptic responses of ET cells to ON input $(30-40 \mu \mathrm{A})$ in voltage clamp. ON stimulation evoked
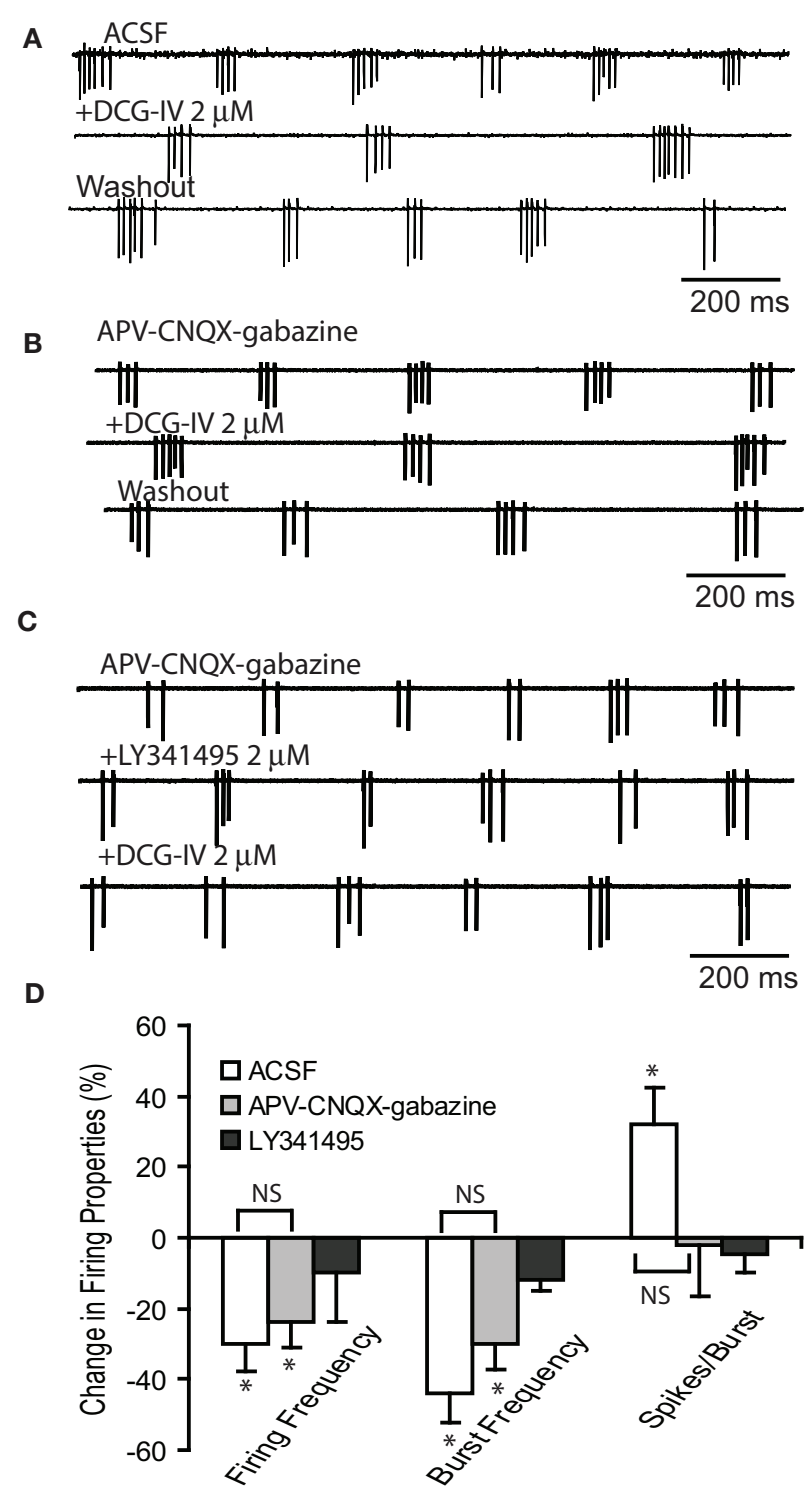

FIGURE 1 | DCG-IV decreases ET cell bursting. (A-C) Extracellular recordings from example ET cells show that DCG-IV $(2 \mu \mathrm{M})$ reversibly reduced the firing frequency and burst rate in in normal ACSF (A) and APV-CNQX-gabazine (B), but had no effect when applied in the presence of LY341495 (C). (D) Group data summarizing the effects of DCG-IV in the conditions in (A-C); ACSF ( $n=$ $6)$, APV-CNQX-gabazine $(n=6)$ and LY341495+APV-CNQX-gabazine $(n=4)$. Data are expressed as percent change from respective control values. ${ }^{*} p<$ 0.05 vs. respective control, paired $t$-tests. NS, non-significant, Kruskal-Willis Test followed by Chi-Square tests; $p=0.81$ for firing frequency, $p=0.47$ for burst frequency, and $p=0.12$ for number of spikes/burst.

short and constant latency EPSCs in ET cells $(1.9 \pm 0.1 \mathrm{~ms}, n$ $=6$, Figure 2A), consistent with monosynaptic mediation (Hayar et al., 2004b; Liu and Shipley, 2008b). DCG-IV (2 $\mu \mathrm{M})$ did not significantly influence the peak amplitude or the integral of $\mathrm{ON}$ evoked EPSCs $(n=5$, Figures 2A,B): peak amplitude, $155.0 \pm$ $51.7 \mathrm{pA}$ vs. $178.0 \pm 60.2 \mathrm{pA}, p=0.24$, paired $t$-test); integral, $1,274 \pm 321$ pA.ms vs. $1,505 \pm 389$ pA.ms, $p=0.30$, paired $t$-test). Similarly, LY341495 ( $2 \mu \mathrm{M}), n=11$, Figures 2C,D) alone did 


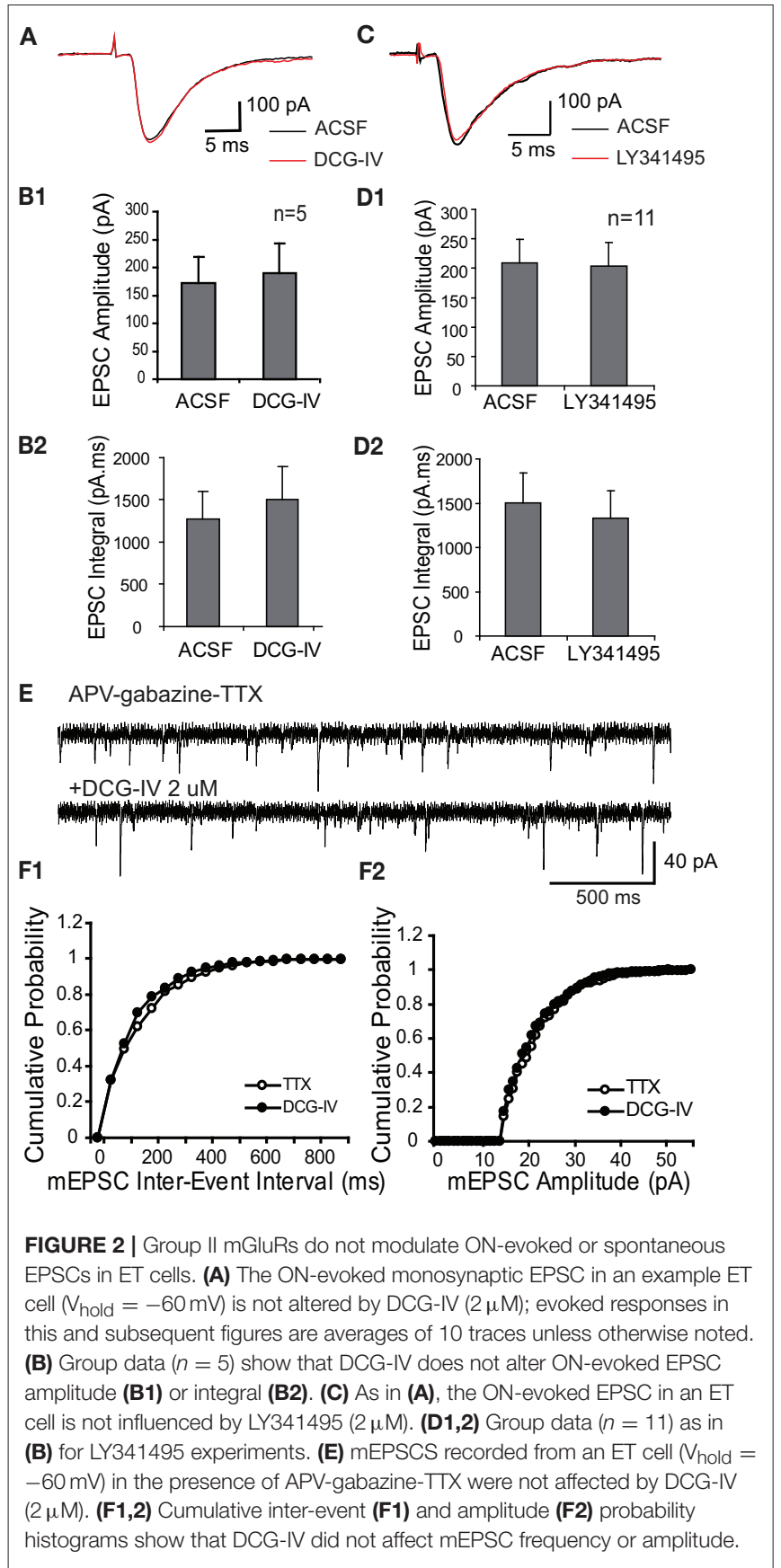

not alter the ON-evoked EPSC peak amplitude (189.2 \pm 39.3 vs. $190.7 \pm 42.6 \mathrm{pA}, p=0.90$, paired $t$-test $)$ or integral $(1,238.3 \pm$ 232.8 pA.ms vs. $1,066.7 \pm 181.4$ pA.ms, $p=0.06$, paired $t$-test).

Consistent with the lack of modulation of the ON-evoked EPSC, DCG-IV did not alter miniature EPSCs (mEPSCs) recorded in ET cells in the presence of APV $(50 \mu \mathrm{M})$, gabazine $(10 \mu \mathrm{M})$, and TTX $(1 \mu \mathrm{M})$ (Figures 2E,F, $n=5)$. mEPSC amplitude (24.6 $\pm 4.6 \mathrm{pA}$ vs. $24.3 \pm 4.1 \mathrm{pA}, p=0.48)$, inter-event intervals ( $14.4 \pm 4.1 \mathrm{~ms}$ vs. $14.5 \pm 5.1 \mathrm{~ms}, p=0.93)$, rise time (1.9 $\pm 0.1 \mathrm{~ms}$ vs. $2.0 \pm 0.1 \mathrm{~ms}, p=0.35)$ and decay time $(6.2 \pm 0.1 \mathrm{~ms}$ vs. $6.5 \pm 0.2 \mathrm{~ms}, p=0.39$ ) were unaffected. Taken together, these results indicate that activation of Group II mGluRs suppresses ET cell firing, but does not presynaptically modulate glutamate release from $\mathrm{ON}$ terminals.

\section{Group I and II mGluRs Differentially Modulate Mitral Cell Excitability}

We next investigated the effects of DCG-IV on mitral cell activity. DCG-IV $(2 \mu \mathrm{M})$ hyperpolarized mitral cells by $-3.2 \pm$ $1.0 \mathrm{mV}(p<0.05$, paired $t$-test, $n=8$, Figures 3A,F). Firing was terminated by DCG-IV in 3 of the 8 cells (Figure 3D). In the 5 cells that continued firing with DCG-IV, firing rate was dramatically reduced from $2.7 \pm 0.6 \mathrm{~Hz}$ to $0.3 \pm 0.1 \mathrm{~Hz}$ $(p<0.01$, paired $t$-test). DCG-IV did not have any discernible effects on spike properties (amplitude, width) and spiking could be restored by depolarizing current injection $(n=2$; data not shown). Contrasting these effects, the influence of DCGIV was negligible in 7 mitral cells with apical dendrites that were truncated between the soma and the glomerular layer (Figure 3B). These cells resting membrane potential $(-53.7 \pm$ $0.7 \mathrm{mV}$ ) was slightly hyperpolarized as compared with intact dendrites $(-51.6 \pm 0.6 \mathrm{mV}, n=17, p>0.11$, unpaired $t$-test $)$. DCG-IV did not hyperpolarize $(-0.6 \pm 0.3 \mathrm{mV}, p=0.08$, paired $t$-test, Figure $3 F)$ or change the firing frequency $(2.8 \pm 0.3 \mathrm{~Hz}$ vs. $2.8 \pm 0.3 \mathrm{~Hz}, p=0.9$, paired $t$-test, Figure $3 \mathrm{E}$ ) in mitral cells with truncated dendrites. These results suggest that the effects of DCG-IV on mitral cells occur in the glomeruli and require intact apical dendrites.

DCG-IV produced similar effects in intact mitral cells in the presence of CNQX-APV-gabazine. DCG-IV hyperpolarized mitral cells by $-3.4 \pm 0.3 \mathrm{mV}(p<0.05, n=7$ paired $t$-test, Figures $3 \mathrm{C}, \mathrm{F})$, a value comparable to that in normal ACSF ( $p=0.85$ unpaired $t$-test, Figure 3F). In all 7 cells, DCG-IV terminated firing $(P<0.05$, paired $t$-test). Surprisingly, application of CNQX-APV-gabazine alone reduced but did not eliminate mitral cell burst frequency $(0.3 \pm 0.1$ vs. $0.2 \pm 0.1 \mathrm{~Hz}$, $p<0.05$ paired $t$-test, Figure 3B). Since spontaneous LLDs, at least in part, generate spike bursts in mitral cells (De Saint Jan et al., 2009), we wondered what mechanism(s) lead to spike bursts when ionotropic glutamate and GABA receptors are blocked. Close inspection of mitral cell current clamp recordings in the presence of CNQX-APV-gabazine revealed spontaneous depolarizing membrane potential oscillations gave rise to spike bursts or single spikes (Figure 4B). Compared to LLDs in normal ACSF (Figure 4A), these oscillations had a lower amplitude and frequency but a similar integral (Figures 4D1-3). The rise and decay times were somewhat longer, but these trends did not reach statistical significance (rise time: $752.2 \pm 172.3 \mathrm{~ms}$ vs. $1,012.8 \pm 202.3 \mathrm{~ms}, p=0.13$, paired $t$-test; decay time: $1,121.8$ $\pm 328.7 \mathrm{~ms}$ vs. $1,179.1 \pm 314.7 \mathrm{~ms}, p=0.89$, paired $t$-test). It is possible that small subtle increases in rise and decay time together may have contributed to the stable integral in the two conditions. The oscillations were also less rhythmic than LLDs as reflected by a higher coefficient of variation of inter-LLD intervals (Figure 4D4). Rhythmic LLDs and oscillations were eliminated by DCG-IV (Figures 4A,B), and were not observed in mitral cells lacking intact apical dendrites (Figure 4C). 
A

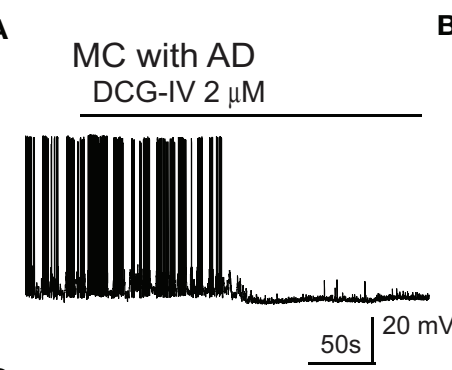

D

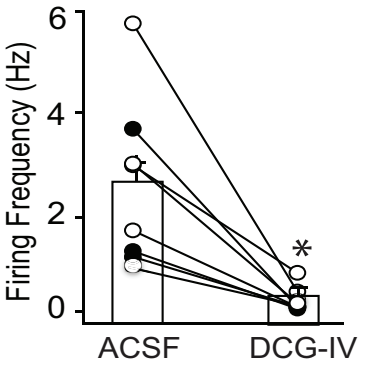

B
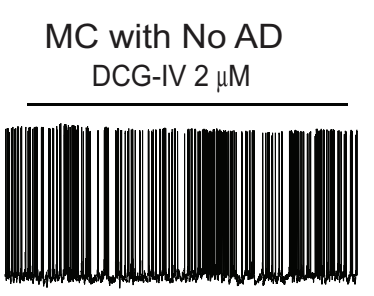

$\left.50 \mathrm{~s}\right|^{20 \mathrm{mV}}$

E

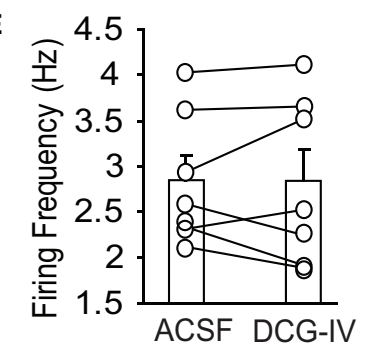

c $\quad \mathrm{MC}$ with $\mathrm{AD}$

APV-CNQX-gabazine

+DCG-IV $2 \mu \mathrm{M}$

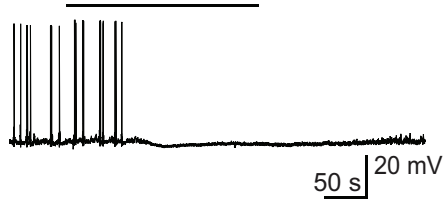

$\mathbf{F}$

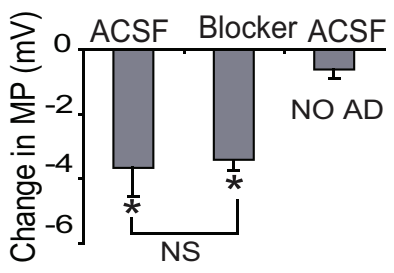

FIGURE 3 | DCG-IV inhibits firing in mitral cells with intact apical dendrites. (A) Example current clamp record showing that $2 \mu \mathrm{M}$ DCG-IV in normal ACSF terminates firing in a mitral cell (MC) with an intact apical dendrite (AD). (B) Firing in an example mitral cell with truncated apical dendrites is unaffected by DGG-IV. (C) DCG-IV applied in the presence of APV-CNQX-gabazine inhibited firing of this mitral cell with intact apical dendrites. (D) Group data showing the effects of DCG-IV on firing frequency of 8 mitral cells with intact apical dendrites. Bars show mean values; closed circles depict the 3 cells that stopped firing after DCG-IV. ${ }^{*} p<0.05$ vs. control, paired $t$-tests. (E) Recording from 7 MCs with apical dendrites truncated showing that DCG-IV had no effect on MC firing frequency. (F) Group data showing the effects of DCG-IV on membrane potential (MP) in mitral cells with intact dendrites in normal ACSF $(n=5)$ or APV-CNQX-gabazine (Blocker, $n=7)$, and in mitral cells with truncated apical dendrites in normal ACSF (No AD, $n=7$ ). ${ }^{*} p<0.05$ vs. control, paired $t$-tests; NS, non-significant, Mann-Whitney U-test.

We further examined the effects of DCG-IV on spontaneous and ON-evoked LLDs in voltage clamp mode. In the presence of APV-gabazine to minimize circuit effects (Figures 5A1,B), DCGIV induced an outward current at $26.1 \pm 8.3 \mathrm{pA}, n=6, p<$ 0.05 paired $t$-test) and decreased LLD frequency by $71.6 \pm 10.2 \%$ $(0.29 \pm 0.04 \mathrm{~Hz}$ to $0.07 \pm 0.02 \mathrm{~Hz}, p<0.01)$. LLD amplitude was unaffected, but the integral was significantly reduced by 70.2 $\pm 6.4 \%(21,965.1 \pm 9,131.6$ pA.ms vs. 7,721.6 $\pm 4,288.2$ pA.ms, $p<0.05$, paired $t$-test) resulting from the significant decreases in the kinetics (rise time: $260.7 \pm 43.2 \mathrm{~ms}$ vs. $120.8 \pm 25.2 \mathrm{~ms}$, $p<0.05$, paired $t$-test; decay time: $453.3 \pm 54.2 \mathrm{~ms}$ vs. 139.1 $\pm 20.9 \mathrm{~ms}, p<0.05$, paired $t$-test). We compared the effects of DCG-IV on spontaneous LLDs to the Group I mGluR1 agonist DHPG, which has previously been shown to robustly increase ET cell bursting and mitral cell firing rate (Heinbockel et al., 2004; Dong et al., 2009). The former effect would be expected to increase LLDs in mitral cells. In the presence of APV-gabazine, DHPG increased LLD frequency by $\sim 100 \%(0.4 \pm 0.1 \mathrm{~Hz}$ to $0.8 \pm 0.1 \mathrm{~Hz}, p<0.05)$, but did not alter LLD amplitude or integral ( $p>0.05$; Figures 5A2,B). Thus, DCG-IV and DHPG exert opposing effects on ET and mitral cell spiking in parallel with opposing effects on mitral cell LLDs.

Finally, we tested the effects of DCG-IV on ON-evoked LLDs. In normal ACSF, ON stimuli $(30-40 \mu \mathrm{A})$ evoked a fast monosynaptic response followed by the delayed LLD as previously reported (Figure 5C; Najac et al., 2011; Shao et al., 2012). DCG-IV $(2 \mu \mathrm{M})$ did not affect the amplitude (160.2 \pm $29.3 \mathrm{pA}$ vs. $161.3 \pm 25.6 \mathrm{pA}, p=0.92)$ or rise time $(4.6 \pm 1.9 \mathrm{~ms}$ vs. $6.3 \pm 2.3 \mathrm{~ms}, p=0.29$ ) of the monosynaptic EPSC component
( $n=6$, Figure 5D1). However, EPSC decay time (752.6 \pm $231.0 \mathrm{~ms}$ vs. $165.0 \pm 47.8 \mathrm{~ms}, p<0.05$, paired test) and integral $(54,294.9 \pm 11,531.0$ pA.ms to $17,412.4 \pm 4,007.9$ pA.ms, $p<$ 0.01) were significantly reduced; Figure 5D2). Taken together, these results show that DCG-IV suppresses spontaneous and ON-evoked LLDs in mitral cells, findings consistent with the suppression of ET cell excitability by DCG-IV.

\section{DCG-IV Decreases Presynaptic Glutamate Input to Periglomerular (PG) Cells}

The preceding data indicate DCG-IV inhibits ET firing and the delayed (i.e., LLD) but not monosynaptic response of mitral cells to ON input. Suppression of the LLD may be due to reduced ET cell excitability but DCG-IV may also independently suppress dendritic glutamate release from these cells. To distinguish between these two actions, we first recorded spontaneous and miniature EPSCs in periglomerular (PG) cells. Most PG cells $(\sim 70 \%)$ respond to ON input polsynaptically via from ET cells while $\sim 30 \%$ receive monosynaptic input from ON terminals (Hayar et al., 2004b; Shao et al., 2009). These two PG cell classes have distinct electrophysiological signatures: ET-driven PG cells exhibit spontaneous bursts of EPSCs and polysynaptic responses to ON input, whereas ON-driven cells exhibit isolated, single spontaneous EPSCs and monosynaptic ON responses (Shao et al., 2009; Kiyokage et al., 2010). Therefore, EPSC activity in ETdriven PG cells is a sensitive reporter of ET cell glutamate release. Voltage clamp recordings were obtained from PG cells exhibiting characteristic polysynaptic sEPSC bursts (Figure 6A). In normal ACSF (Figures 6A,B), DCG-IV $(2 \mu \mathrm{M}, n=6)$ reduced overall 

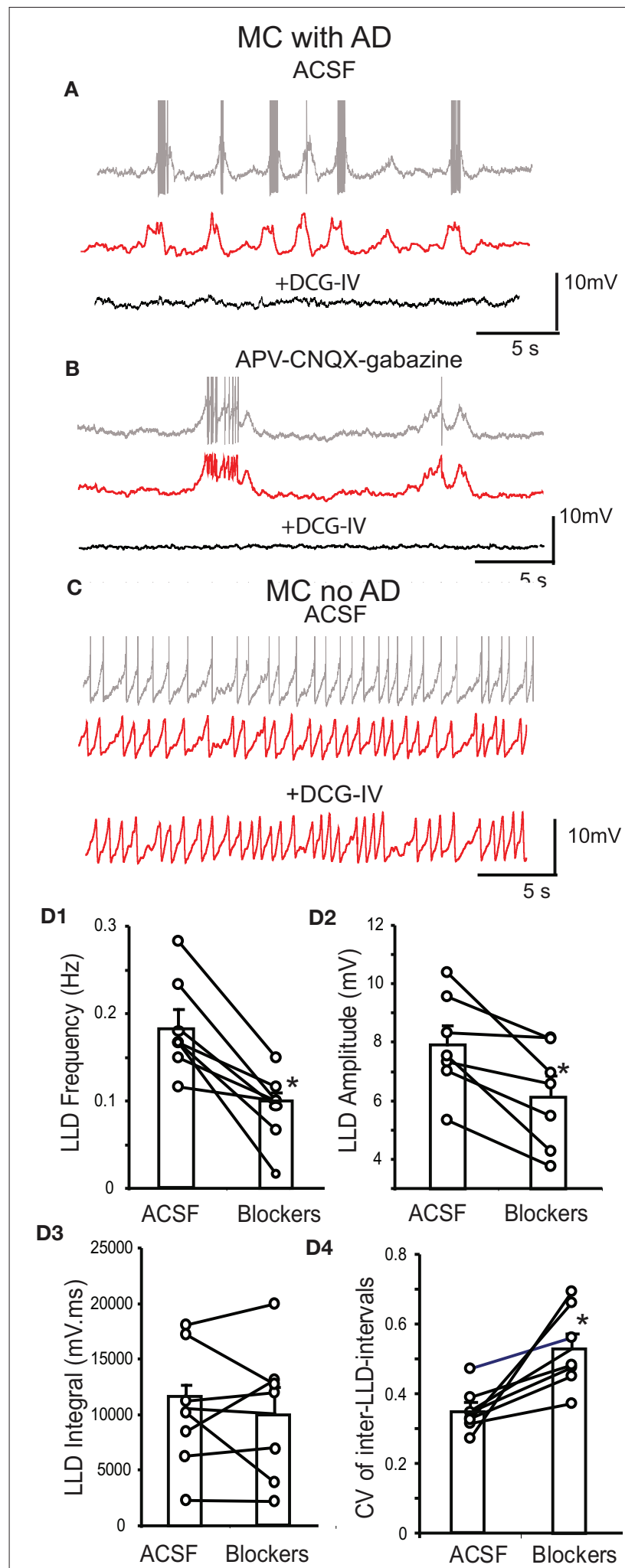

FIGURE 4 | Spontaneous LLDs and membrane potential oscillations in mitra cells. (A) Upper trace - example current clamp record shows that a mitral cell (MC) with an intact apical dendrite (AD) in normal ACSF exhibits rhythmic

(Continued)
FIGURE 4 | bursting associated with LLDs. Middle trace - low pass filtered record of upper trace more clearly reveals underlying LLDs. Lower trace DCG-IV eliminates spiking and LLDs. (B) In APV-CNQX-gabazine, this mitral cell with intact apical dendrite exhibits spike bursts or single spikes associated with LLD-like membrane potential oscillations (upper trace), as also seen in the middle filtered trace. Lower trace - DCG-IV terminates spiking and membrane potential oscillations. (C) An example mitral cell with truncated apical dendrites does not exhibit LLD-like membrane potential oscillations in raw (upper) or filtered traces (middle, lower). (D1-4) Mitral cell group data showing LLD properties in normal ACSF and APV-CNQX-gabazine; $n=7,{ }^{*} p<0.05$, paired t-tests.

sEPSC frequency by $74.7 \pm 8.2 \%(8.9 \pm 2.5 \mathrm{~Hz}$ vs. $1.8 \pm 0.6 \mathrm{~Hz}$, $p<0.05$, paired $t$-test,) and sEPSC burst frequency by $85.4 \pm$ $20.0 \%(0.5 \pm 0.2 \mathrm{~Hz}$ vs. $0.04 \pm 0.21 \mathrm{~Hz}, p<0.05$, paired $t$ test); sEPSC amplitude was not significantly affected (29.9 \pm 3.7 pA vs. $24.6 \pm 1.9$ pA, $p>0.05$, paired $t$-test, Figure 6B). We next investigated miniature EPCSs (mEPSCs) in the presence of APV $(50 \mu \mathrm{M})$, gabazine $(10 \mu \mathrm{M})$ and TTX $(1 \mu \mathrm{M})$. Under these conditions, bursts of EPSCs were eliminated ( $n=5$, Figure $6 \mathrm{C}$ ), consistent with the absence of ET cell spiking in TTX (Hayar et al., 2004a; Liu and Shipley, 2008b). mEPSC frequency was also less than that in normal ACSF. DCG-IV significantly decreased mEPSC frequency by $48.6 \pm 9.4 \%(1.9 \pm 0.4 \mathrm{~Hz}$ vs. $1.0 \pm 0.3 \mathrm{~Hz}$ $(p<0.01$, paired $t$-test); mEPSC amplitude ( $23.8 \pm 1.3$ pA vs. 22.8 $\pm 1.5 \mathrm{pA}$ ) and kinetics (rise time: $1.6 \pm 0.1 \mathrm{~ms}$ vs. $1.8 \pm 0.1 \mathrm{~ms}$, decay time: $4.3 \pm 0.3 \mathrm{~ms}$ vs. $4.1 \pm 0.3 \mathrm{~ms}$ ) were not significantly changed $(p>0.05$, paired $t$-tests, Figure 6D). The reduction of mEPSC frequency, without effects on mEPSC amplitude or kinetics, suggests that DCG-IV presynaptically inhibits ET cell dendritic glutamate release. Finally, DCG-IV did not significantly affect the holding current in these recordings $(0.79 \pm 1.72 \mathrm{pA}, \mathrm{p}$ $=0.67, n=5$, paired $t$-test).

We next examined the effects of DCG-IV on PG cell polysynaptic responses to $\mathrm{ON}$ input, reasoning that the suppression of ET cell glutamate release would suppress the ONevoked responses in these ET-driven PGs cells. ON stimulation (30-40 $\mu \mathrm{A})$ evoked relatively long and variable latency EPSCs in PG cells exhibiting spontaneous EPSC bursts as previously reported (Figure 6E1; Hayar et al., 2004b; Shao et al., 2009). The mean latency of the ON-evoked EPSC was $4.0 \pm 0.6 \mathrm{~ms}$, $n=6$ ) and the mean jitter (standard deviation of the latency) was $1,322.9 \pm 459.2 \mu \mathrm{s}, n=6)$. DCG-IV $(2 \mu \mathrm{M})$ significantly decreased EPSCs amplitude (132.9 \pm 35.4 pA vs. $88.2 \pm 23.3$ pA, $p<0.05$, paired $t$-test $)$ and integral $(3,603.7 \pm 1,169.3 \mathrm{pA} . \mathrm{ms}$ vs. $2,849.2 \pm 890.5$ pA.ms, $p<0.05 ; n=6$, Figure 6E1-3). These results are consistent with presynaptic inhibition of ET cell glutamate release by DCG-IV.

\section{DCG-IV Reduces Feedback Glutamate Release in External Tufted Cells}

The preceding results indicate that DCG-IV presynaptically reduces glutamate release from ET cells. To further extend these findings, we investigated the effect of DCG-IV on self-excitation elicited by depolarization of single ET cells ( -60 to $0 \mathrm{mV}, 5 \mathrm{~ms}$ duration) in voltage clamp recordings. As shown in Figure 7A1, 


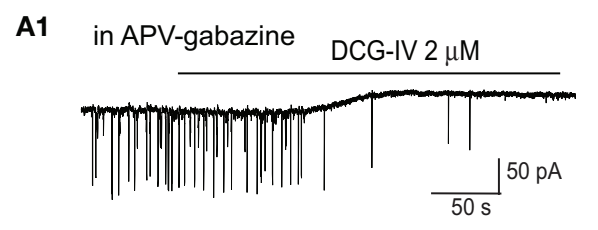

A2

in APV-gabazine

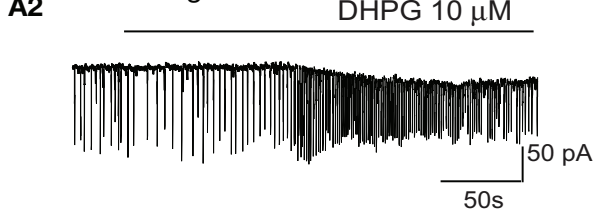

D1

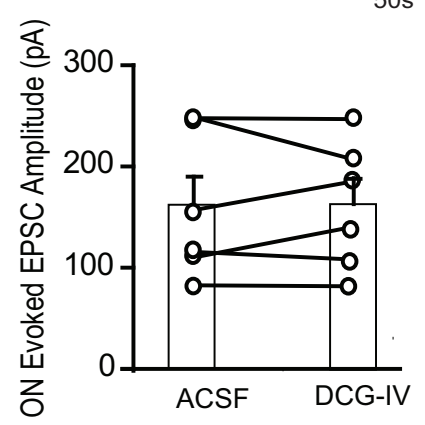

B

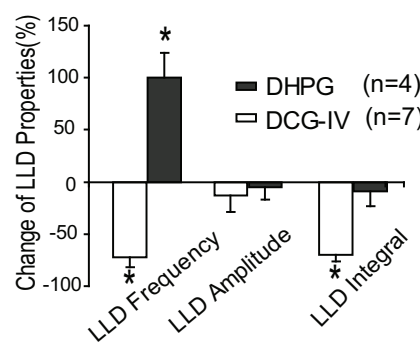

C

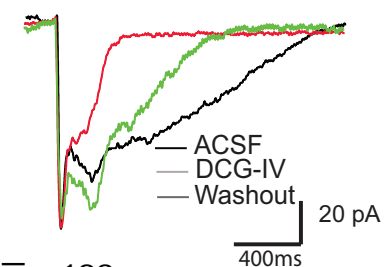

D2

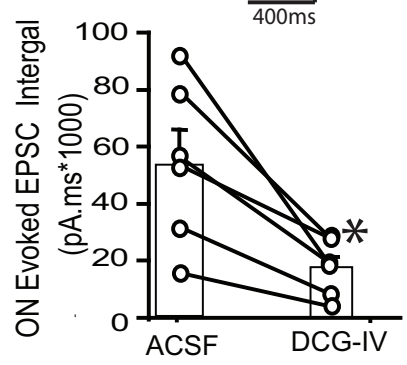

FIGURE 5 | DCG-IV suppresses mitral cell spontaneous and ON-evoked LLDs. (A) Example mitral cell voltage clamp records $\left(V_{\text {hold }}=-60 \mathrm{mV}\right)$ in the presence of APV-gabazine show that DCG-IV (A1) suppresses while DHPG (A2) increases spontaneous LLDs. (B) Group data showing the effects of DCG-IV and DHPG on LLD properties. ${ }^{*} p<0.05$ vs. respective control. (C) In normal ACSF, ON stimulation evoked a rapid monosynaptic EPSC followed by longer duration LLD. The LLD, but not the monosynaptic EPSC, was suppressed by DCG-IV $(2 \mu \mathrm{m})$. (D1,2) Group data $(n=6)$ showing the effects of DCG-IV on the monosynaptic EPSC amplitude (D1) and the EPSC integral (D2); ${ }^{*} p<0.05$ vs. control.

single depolarizing steps elicited an inward current that was significantly reduced by APV $(50 \mu \mathrm{M})$ and CNQX $(10 \mu \mathrm{M})$; $69.8 \pm 11.1 \%$ reduction of the inward current integral $(n=$ $6, p<0.05$, paired $t$-test). DCG-IV $(2 \mu \mathrm{M})$ reversibly reduced the inward current integral (Figures 7A2,B,C) by $55.2 \pm 9.0 \%$ (4,284.2 $\pm 1,147.6$ pA.ms vs. $1,805.8 \pm 463.0$ pA.ms, $p<0.05$, paired $t$-test, $n=8)$. LY341495 $(1 \mu \mathrm{M})$ itself did not affect the inward current, but prevented the reduction by DCG-IV (ACSF: 4,237.1 \pm 2,196.4 pA.ms, LY341495: 4,476.9 \pm 2,339.6 pA.ms, LY341495+DCG-IV: 4,219.7 $\pm 2,208.4$ pA.ms; $n=3, p>0.19$, One way repeated measures ANOVA, Figures 7A3,B). These results provide additional evidence that DCG-IV suppresses glutamate release from ET cells.

\section{DISCUSSION}

The present results indicate that activation of Group II mGluRs directly inhibits ET and mitral cells, and reduces glutamate release from ET cells. These effects occur in the absence of modulation of monosynaptic responses to ON input. However, the inhibition of ET and mitral tufted excitability suppresses intraglomerular glutamate release that generates polysynaptic responses of PG cells to ON input and the generation of LLDs in mitral cells.
DCG-IV uniformly reduced the excitability of ET and mitral cells assessed by membrane potential hyperpolarization and suppression of spontaneous firing. These actions persisted to an equivalent degree in the presence of ionotropic glutamate and GABA receptor antagonists, suggesting a direct effect on the recorded cells. Although Group II mGluRs are well known for presynaptic modulation of neurotransmitter release, they have also been linked to direct membrane hyperpolarization and inhibition of spiking (Bandrowski et al., 2003; Watanabe and Nakanishi, 2003; Govindaiah and Cox, 2006; Mateo and Porter, 2007; Lee and Sherman, 2009; Wang et al., 2012). Inhibition of spiking by DCG-IV was restored by positive current injection, which together with the lack of effect on spike properties, indicate that modulation of fast sodium channels was not involved. The hyperpolarization, and corresponding outward current in voltage clamp, suggest that opening of potassium channels and/or closure of calcium channels near resting threshold may be involved, consistent with cellular actions of Group II mGluRs (Knoflach and Kemp, 1998; Anwyl, 1999; Dutar et al., 2000; Watanabe and Nakanishi, 2003; Lee and Sherman, 2009). Additional studies are needed to establish the ionic basis of Group II mGluRs inhibitory actions on mitral and ET cells. As ET and PG cell processes are confined to the glomerular layer, and DCG-IV effects were absent in mitral cells lacking apical 
A

$\mathrm{Hp}=-60 \mathrm{mV}$

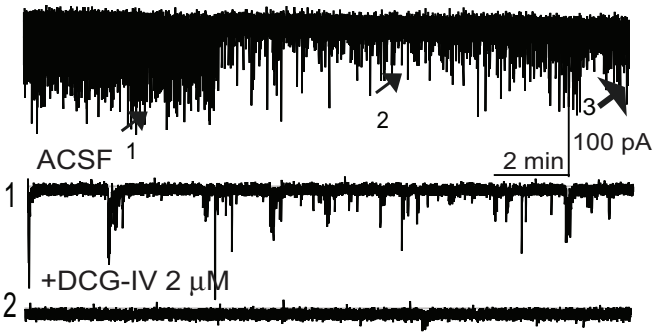

Washout

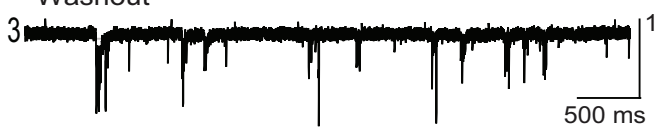

B

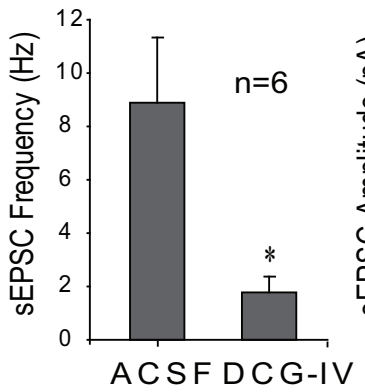

E1

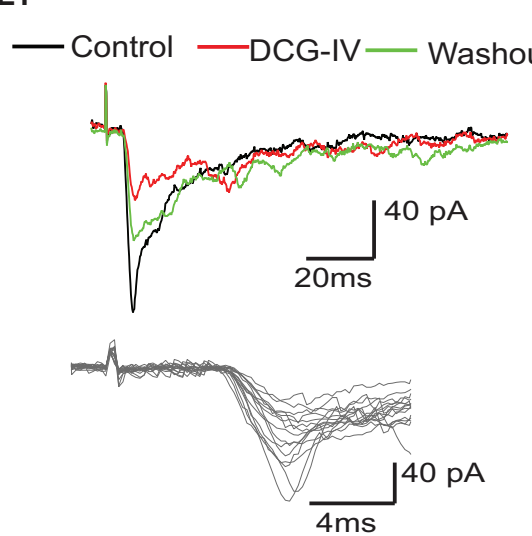

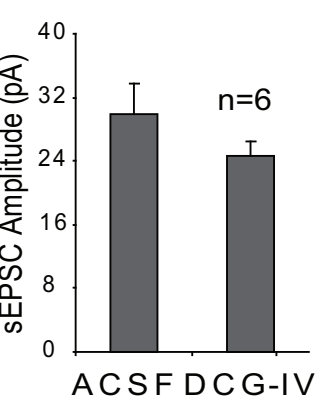

E2

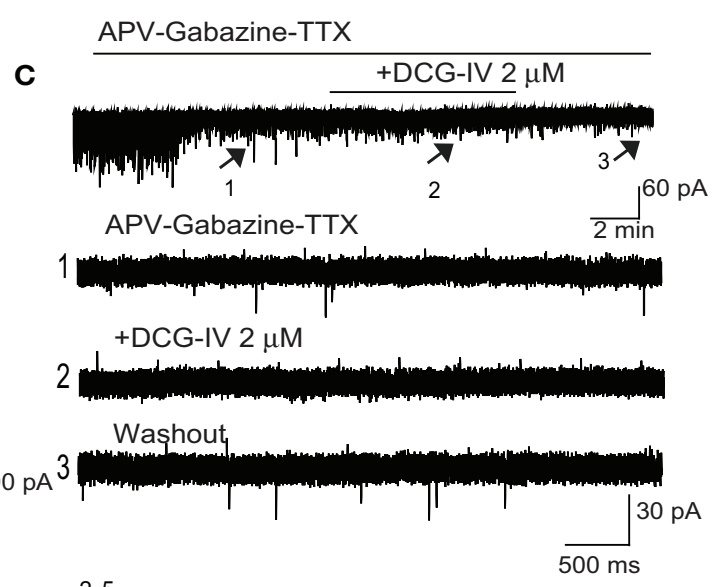

2.5
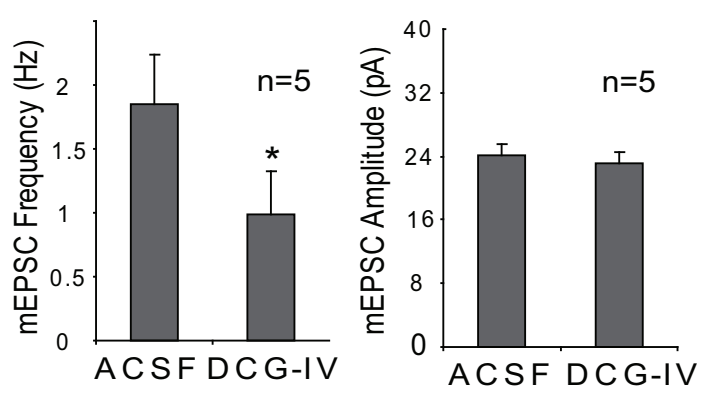

E3

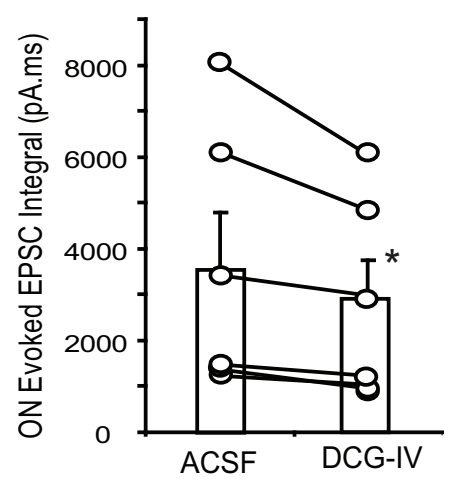

FIGURE 6 | DCG-IV decreases spontaneous and ON-evoked EPSCs in PG cells. (A) PG cell voltage clamp recordings $\left(V_{\text {hold }}=-60 \mathrm{mV}\right)$ shows that DCG-IV $(2 \mu \mathrm{M})$ suppresses sEPSCs. Lower traces show faster time scale records at indicated time points. (B) Group data showing that DCG-IV significantly decreases sEPSC frequency but not amplitude; * $p<0.05$ compared to control. (C) mEPSCs recorded in the presence of APV-gabazine-TTX are suppressed by DCG-IV, as also shown in lower, faster time scale traces. (D) Group data showing DCG-IV significantly decreases mEPSC frequency but not amplitude; ${ }^{*} p<0.05$, compared to control. (E1) ON-evoked polysynaptic EPSCs in a PG cell were suppressed by DCG-IV $(2 \mu \mathrm{M})$. Lower faster timescale traces show jitter in EPSC onset latency. (E2,3) Group data ( $n=6$ PG cells) showing the effect of DCG-IV on EPSC peak amplitude (E2) and integral (E3). ${ }^{*} p<0.05$ vs. control, paired $t$-test.

dendrites, the anatomical locus of the Group II mGluR action(s) appear to be in the glomeruli.

In addition to postsynaptic inhibitory actions, several findings indicate that activation of Group II mGluRs presynaptically inhibit glutamate release from ET and possibly mitral cells. First, DCG-IV suppressed spontaneous LLDs in mitral cells and the late "LLD" component of ON-evoked responses. It might be argued that these effects are secondary to inhibition of spiking in ET and mitral cells. However, DCG-IV did not alter the monosynaptic ON response in either cell type, also consistent with lack of presynaptic modulation of ON glutamate release as judged from mEPSC measurements in ET cells. Second, DCG-IV reduced the frequency, but not amplitude or kinetics, of mEPSCs in the class of PG cells that receive indirect ON input via ET cells, i.e., ET-driven PG cells (Hayar et al., 2004b; Shao et al., 2009). DGG-IV also reduced the polysynaptic ON response in these ETdriven PG cells. Third, DCG-IV suppressed evoked glutamate release from individual ET cells. These findings in aggregate are 


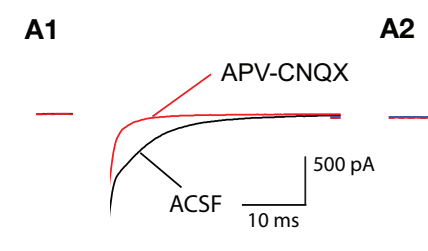

B

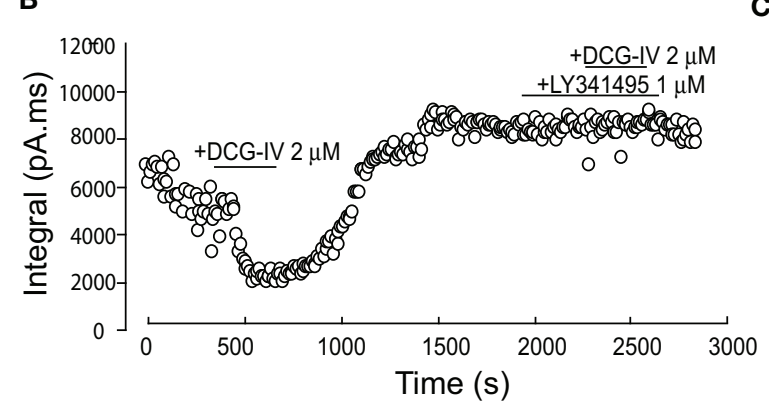

A3

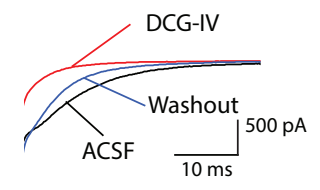

C
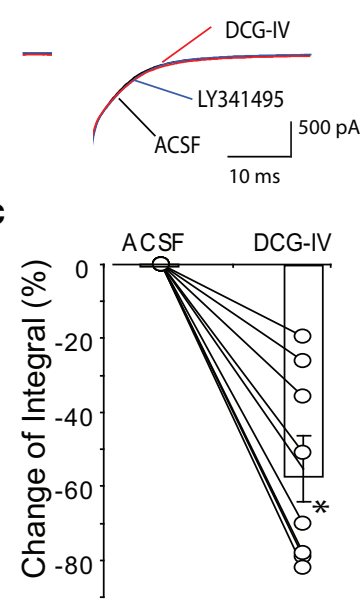

FIGURE 7 | DCG-IV suppressed ET cell self-excitation. (A1) Example voltage clamp record showing that a depolarizing step (-60 to $0 \mathrm{mV}, 5 \mathrm{~ms}$; artifact blanked) elicited an inward current or self-excitation in this ET cell that was eliminated by APV-CNQX. (A2) The evoked current was reversibly suppressed by DCG-IV (2 $\mu$ M). (A3) DCG-IV had no effect in the presence of LY341495 (1 $\mu \mathrm{M})$. (B) Time-running plot showing the integral of the self-excitatory current was reduced by DCG-IV and this effect was blocked by pretreatment of group II mGluR antagonist LY341495. (C) Group data from 8 ET cells (open circles) showing the decrease in the normalized inward current integral; bar represents the mean change. ${ }^{*} p<0.05$ vs. control, paired $t$-test.

in agreement with presynaptic inhibition of transmitter release by Group II mGluRs in numerous brain circuits (Anwyl, 1999), including glutamate from mitral cells (Schoppa and Westbrook, 1997) and GABA release from granule and PG cells (Zak et al., 2015). Our findings are also consistent with the observations of Zak et al. (2015) that DCG-IV hyperpolarized mitral cells and did not influence ON-evoked monosynaptic EPSCs in ET cells. Our findings however contrast the findings of this study that Group II mGluR activation and inactivation respectively enhanced or inhibited ON-evoked LLDs, and that DCG-IV did not influence PG cell polysynaptic responses to ON stimulation (Zak et al., 2015). The enhancement of ON-evoked LLDs by DCG-IV in the Zak et al. study was attributed to extrasynpatic spillover of glutamate from ET cells that activated Group II receptors on PG cells leading to decreased GABA release, i.e., disinhibition. However, GABAergic disinhibition cannot account for the similar inhibitory effects of DCG-IV observed in normal ACSF, APV-gabazine and APV-CNQX-gabazine in the present study. The differing results of Zak et al. (2015) may be due to the use of younger mice (postnatal day 8-15) and/or the presence of a GABAb receptor antagonist in the ACSF. Additionally, the disinhibitory actions of Group II mGluRs in the Zak et al. (2015) study were in part based on use of an mGluR2 antagonist, which may also potentially underlie differences with the present study.

The prolonged spontaneous depolarizations observed in mitral cells in the presence of APV-CNQX-gabazine have not been previously reported to our knowledge. This depolarization was associated with single spikes or spike bursts. They resemble LLDs observed in normal ACSF with respect to frequency and duration, but are smaller in amplitude and less rhythmic. With a frequency less than $0.3 \mathrm{~Hz}$, they are slower than the $10-20 \mathrm{~Hz}$ or gamma frequency subthreshold membrane potential oscillations previously reported for mitral cells in vitro (Desmaisons et al., 1999; Friedman and Strowbridge, 2003). They also do not appear to correspond to the upstate of mitral cell bistability, which is typically shorter in duration $(20-500 \mathrm{~ms})$ and uniformly terminated by a spike (Heyward et al., 2001). The prolonged depolarizations were absent in mitral cells lacking intact apical dendrites, suggesting a common glomerular origin with LLDs (Carlson et al., 2000). Candidate mechanisms that may generate these depolarization in synaptic blockers are: (1) an excitatory chemical transmitter released in the glomeruli, e.g., excitatory actions of glutamate acting at mGluR1 (Schoppa and Westbrook, 2001; Heinbockel et al., 2004; Yuan and Knopfel, 2006), cholecystokinin (Ma et al., 2013) or $\beta$ adrenoreceptors (Nai et al., 2010; Zhou et al., 2016); and (2) an intrinsic membrane current such as a sustained sodium current; and/or depolarizations transmitted by electrical synapses between glutamatergic apical dendrites in the glomeruli (Schoppa and Westbrook, 2002; Christie et al., 2005; Hayar et al., 2005; Ma and Lowe, 2007; Pimentel and Margrie, 2008; De Saint Jan et al., 2009).

The suppression of ET and mitral cell excitability by Group II mGluRs in the mature MOB network contrasts with the net excitatory effects of Group I mGluR activation. Group I mGluRs, and in particular mGluR1, contribute to ET and mitral cell excitation in response to $\mathrm{ON}$ stimulation in vitro (Heinbockel et al., 2004; De Saint Jan and Westbrook, 2005; Ennis et al., 2006; Dong et al., 2009) and odor responses in vivo (Matsumoto et al., 2009). These and other studies (Schoppa and Westbrook, 2001; Yuan and Knopfel, 2006) indicate that activation of Group I receptors in the glomerular enhance and amplify ET and mitral/tufted cells responses to ON input and are also recruited by glutamate spillover to enhance the generation of LLDs and slow rhythmic oscillations in the glomerular network. 
By contrast, the present findings suggest that Group II receptor activation operate in an opposite manner to suppress glutamate spillover in the glomeruli and hence dampen the expression of LLDs and rhythmic oscillations. If Group II mGluRs are preferentially engaged by strong or relatively high frequency input ON input (Zak et al., 2015), perhaps during fast sniffing, this may serve to truncate self- and lateral excitation mediated by intraglomerular glutamate release. This could serve as a gain control to modulate the dynamic range of mitral/tufted cell odor responses, and/or to temporally sharpen spike responses to the sniff rhythm. Together, our data point to another feature of intraglomerular circuits (glutamate spillover, LLDs, electrical synapses, presynaptic inhibition of ON terminals, PG cellmediated feedback and feedforward inhibition) that function to

\section{REFERENCES}

Anwyl, R. (1999). Metabotropic glutamate receptors: electrophysiological properties and role in plasticity. Brain Res. Train Res. Rev. 29, 83-120. doi: 10.1016/S0165-0173(98)00050-2

Bandrowski, A. E., Huguenard, J. R., and Prince, D. A. (2003). Baseline glutamate levels affect group I and II mGluRs in layer V pyramidal neurons of rat sensorimotor cortex. J. Neurophysiol. 89, 1308-1316. doi: $10.1152 /$ in. 00644.2002

Carlson, G. C., Shipley, M. T., and Keller, A. (2000). Long-lasting depolarizations in mitral cells of the rat olfactory bulb. J. Neurosci. 20, 2011-2021.

Christie, J. M., Bark, C., Hormuzdi, S. G., Helbig, I., Monyer, H., and Westbrook, G. L. (2005). Connexin 36 mediates spike synchrony in olfactory bulb glomeruli. Neuron 46, 761-772. doi: 10.1016/j.neuron.2005.04.030

Conn, P. J., and Pin, J. P. (1997). Pharmacology and functions of metabotropic glutamate receptors. Ann. Rev. Pharmacol. Toxicol. 37, 205-237. doi: 10.1146/annurev.pharmtox.37.1.205

De Saint Jan, D., Hirnet, D., Westbrook, G. L., and Charpak, S. (2009). External tufted cells drive the output of olfactory bulb glomeruli. J. Neurosci. 29, 2043-2052. doi: 10.1523/JNEUROSCI.5317-08.2009

De Saint Jan, D., and Westbrook, G. L. (2005). Detecting activity in olfactory bulb glomeruli with astrocyte recording. J. Neurosci. 25, 2917-2914. doi: 10.1523/JNEUROSCI.5042-04.2005

Desmaisons, D., Vincernt, J. D., and Lledo, P. M. (1999). Control of action potential timing by intrinsic subthreshold oscillations in olfactory bulb output neurons. J. Neurosci. 19, 10727-10737.

Dong, H. W., and Ennis, M. (2014). Activation of group I metabotropic glutamate receptors enhances persistent sodium current and rhythmic bursting in main olfactory bulb external tufted cells. J. Neurophysiol. 111, 741-647. doi: $10.1152 /$ jn.00696.2013

Dong, H. W., Hayar, A., Callaway, J., Yang, X. H., Nai, Q., and Ennis, M. (2009). Group I mGluR activation enhances $\mathrm{Ca}^{2+}$-dependent nonselective cation currents and rhythmic bursting in main olfactory bulb external tufted cells. $J$. Neurosci. 29, 11943-11953. doi: 10.1523/JNEUROSCI.0206-09.2009

Dong, H. W., Hayar, A., and Ennis, M. (2007). Activation of group I metabotropic glutamate receptors on main olfactory bulb granule cells and periglomerular cells enhances synaptic inhibition of mitral cells. J. Neurosci. 27, 5654-5663. doi: 10.1523/JNEUROSCI.5495-06.2007

Dutar, P., Petrozzino, J. J., Vu, H. M., Schmidt, M. F., and Perkel, D. J. (2000). Slow synaptic inhibition medicated by metabotropic glutamate receptor activation of GIRK channels. J. Neurophysiol. 84, 2284-2290. doi: 10.1152/jn.2000.84.5.2284

Ennis, M., Zhu, M., Heinbockel, T., and Hayar, A. (2006). Olfactory nerve-evoked, metabotropic glutamate receptor-mediated synaptic responses in rat olfactory bulb mitral cells. J. Neurophysiol. 95, 2233-2241. doi: 10.1152/jn.01150.2005

Friedman, D., and Strowbridge, B. W. (2003). Both electrical and chemical synapses mediate fast network oscillations in the olfactory bulb. J. Neurophysiol. 89, 1601-2610. doi: 10.1152/jn.00887.2002 dynamically modulate the strength and temporal precision of odor responses.

\section{AUTHOR CONTRIBUTIONS}

H-WD designed the study, performed experiments, analyzed the results, wrote the article and approved the final version of the manuscript. ME designed the study, modified the manuscript and approved the final version of the manuscript.

\section{ACKNOWLEDGMENTS}

This work was supported by National Institutes of Health grant: DC003195.

Govindaiah, G., and Cox, C. L. (2006). Metabotropic glutamate receptors differentially regulate GABAergic inhibition in thalamus. J. Neurosci. 26, 13443-13453. doi: 10.1523/JNEUROSCI.3578-06.2006

Hayar, A., and Ennis, M. (2007). Endogenous GABA and glutamate finely tune the bursting of olfactory bulb external tufted cells. J. Neurophysiol. 98, 1052-1056. doi: 10.1152/jn.01214.2006

Hayar, A., Karnup, S., Ennis, M., and Shipley, M. T. (2004a). Olfactory bulb glomeruli: external tufted cells intrinsically burst at theta frequency and are entrained by patterned olfactory input. J. Neurosci. 24, 1190-1199. doi: 10.1523/JNEUROSCI.4714-03.2004

Hayar, A., Karnup, S., Ennis, M., and Shipley, M. T. (2004b). External tufted cells: a major excitatory element that coordinates glomerular activity. J. Neurosci. 24, 6676-6685. doi: 10.1523/JNEUROSCI.1367-04.2004

Hayar, A., Shipley, M. T., and Ennis, M. (2005). Olfactory bulb external tufted cells are synchronized by multiple intraglomerular mechanisms. J. Neurosci. 25, 8197-8208. doi: 10.1523/JNEUROSCI.2374-05.2005

Hayashi, Y., Momiyama, A., Takahashi, T., Ohishi, H., Ogawa-Meguro, R., Shigemoto, R., et al. (1993). Role of a metabotropic glutamate receptor in synaptic modulation in the accessory olfactory bulb. Nature 16, 687-690. doi: $10.1038 / 366687 \mathrm{a} 0$

Heinbockel, T., Heyward, P., Conquet, F., and Ennis, M. (2004). Regulation of main olfactory bulb mitral cell excitability by metabotropic glutamate receptor mGluR1. J. Neurophysiol. 92, 3085 33096. doi: 10.1152/jn.00349.2004

Heinbockel, T., Larris, N., and Ennis, M. (2007). Metabotropic glutamate receptors in the main olfactory bulb drive granule cell-mediated inhibition. $J$. Neurophysiol. 97, 858-870. doi: 10.1152/jn.00884.2006

Heyward, P., Ennis, M., Keller, A., and Shipley, M. T. (2001). Membrane bistability in olfactory bulb mitral cells. J. Neurosci. 21, 5311-5320.

Ishida, M., Saitoh, T., Shimamoto, S. K., Ohfune, Y., and Shinozaki, O. H. (1993). A novel metabotropic glutamate receptor agonist: marked depression of monosynaptic excitation in the newborn rat isolated spinal cord. Br. J. Pharmacol. 109, 1169-1177. doi: 10.1111/j.1476-5381.1993. tb13745.x

Kingston, A. E., Lowndes, J., Evans, N., Clark, B., Tomlinson, R., Burnett, J. P., et al. (1998). Sulphur-containing amino acids are agonists for group I metabotropic receptors expressed in clonal RGT cell lines. Neuropharmacology 37, 277-287. doi: 10.1016/S0028-3908(98)00018-5

Kirschstein, T., von der Brelie, C., Steinhäuser, M., Vinçon, A., Beck, H., and Dietrich, D. (2004). L-CCG-I activates group III metabotropic glutamate receptors in the hippocampal CA3 region. Neuropharmacology. 47, 157-162. doi: 10.1016/j.neuropharm.2004.04.004

Kiyokage, E., Pan, Y. Z., Shao, Z., Kobayashi, K., Szabo, G., Yannagawa, Y., et al. (2010). Molecular identifty of periglomerular and short axon cells. J. Neurosci. 30, 1185-1196. doi: 10.1523/JNEUROSCI.3497-09.2010

Knoflach, F., and Kemp, J. A. (1998). Metabotropic glutamate group II receptors activate a $\mathrm{G}$ protein-coupled inwardly rectifying $\mathrm{K}+$ current in neurons of the rat cerebellum. J. Physiol. 509, 347-354. 
Lee, C. C., and Sherman, S. M. (2009). Glutamatergic inhibition in sensory neocortex. Cereb. Cortex. 19, 2281-2289. doi: 10.1093/cercor/bhn246

Liu, S., and Shipley, M. T. (2008a). Intrinsic conductance actively shape excitatory and inhibitory postsynaptic responses in olfactory bulb external tufted cells. J. Neurosci. 28, 10311-10322. doi: 10.1523/JNEUROSCI.260808.2008

Liu, S., and Shipley, M. T. (2008b). Multiple conductance cooperatively regulate spontaneous bursting in mouse olfactory bulb external tufted cells. J. Neurosci. 28, 1625-1639. doi: 10.1523/JNEUROSCI.3906-07.2008

Ma, J., Dankulich-Nagrudny, L., and Lowe, G. (2013). Cholecystokinin: an excitatory modulator of mitral/tufted cells in the mouse olfactory bulb. PLoS ONE 8:e64170. doi: 10.1371/journal.pone.0064170

Ma, J., and Lowe, G. (2007). Calcium permeable AMPA receptors and autoreceptors in external tufted cells of rat olfactory bulb. Neuroscience 144, 1094-1108. doi: 10.1016/j.neuroscience.2006.10.041

Mateo, Z., and Porter, J. T. (2007). Group II metabotropic glutamate receptors inhibit glutamate release at thalamocortical synapses in the developing somatosensory cortex. Neuroscience 146, 1062-1072. doi: 10.1016/j.neuroscience.2007.02.053

Matsumoto, H., Kashiwadani, H., Nagao, H., Aiba, A., and Mori, K. (2009). Odorinduced persistent discharge of mitral cells in the mouse olfactory bulb. J. Neurophysiol. 101, 1890-1900. doi: 10.1152/jn.91019.2008

Nai, Q., Dong, H. W., Linster, C., and Ennis, M. (2010). Activation of alpha1 and alpha2 noradrenergic receptors exert opposing effects on excitability of main olfactory bulb granule cells. Neuroscience 169, 882-892. doi: 10.1016/j.neuroscience.2010.05.010

Najac, M., De Saint Jan, D., Reguero, L., Grandes, P., and Charpak, S. (2011). Monosynaptic and polysynaptic feed-forward inputs to mitral cells from olfactory sensory neurons. J. Neurosci. 31, 8722-8729. doi: 10.1523/JNEUROSCI.0527-11.2011

Neki, A., Ohishi, H., Kaneko, T., Shigemoto, R., Nakanishi, S., and Mizuno, N. (1996). Pre-and postsynaptic localization of a metabotropic glutamate receptor, mGluR2, in the rat brain: and immunohistochemical study with a monoclonal antibody. Neurosci. Lett. 202, 197-200. doi: 10.1016/0304-3940(95) 12248-6

Ohishi, H., Neki, A., and Mizuno, N. (1998). Distribution of a metabotropic glutamate receptor, mGluR2, in the central nervous system of the rat and mouse: an immunohistochemical study with a monoclonal antibody. Neurosci. Res. 30, 65-82. doi: 10.1016/S0168-0102(97)00120-X

Ohishi, H., Shigemoto, R., Nakanishi, S., and Mizuno, N. (1993). Distribution of the mRNA for a metabotropic glutamate receptor (mGluR3) in the rat brain: an in situ hybridization study. J. Comp. Neurol. 335, 252-266. doi: 10.1002/cne.903350209

Petralia, R. S., Wang, Y. X., Niedzielski, A. S., and Wenthold, R. J. (1996). The metabotropic glutamate receptors, mGluR2 and mGluR3, show unique postsynaptic, presynaptic and glial localizations. Neuroscience 71, 949-976. doi: 10.1016/0306-4522(95)00533-1

Pimentel, D. O., and Margrie, T. W. (2008). Glutamatergic transmission and plasticity between olfactory bulb mitral cells. J. Physiol. 586, 2107-2119. doi: 10.1113/jphysiol.2007.149575

Sahara, Y., Kubota, T., and Ichikawa, M. (2001). Cellular localization of metabotropic glutamate receptors mGluR1, 2/3, 5 and 7 in the main and accessory olfactory bulb of the rat. Neurosci. Lett. 312, 59-62. doi: 10.1016/S0304-3940(01)02184-X
Salin, P. A., Lledo, P. M., Vincent, J. D., and Charpak, S. (2001). Dendritic glutamate autoreceptors modulate signal processing in rat mitral cells. $J$. Neurophysiol. 85, 1275-1282. doi: 10.1152/jn.2001.85.3.1275

Schoppa, N. E., and Westbrook, G. L. (1997). Modulation of mEPSCs in olfactory bulb mitral cells by metabotropic glutamate receptors. J. Neurophysiol. 78, 1368-1375. doi: 10.1152/jn.1997.78.3.1468

Schoppa, N. E., and Westbrook, G. L. (2001). Glomerulus-specific synchronization of mitral cells in the olfactory bulb. Neuron 31, 639-651. doi: 10.1016/S0896-6273(01)00389-0

Schoppa, N. E., and Westbrook, G. L. (2002). AMPA autoreceptors drive correlated spiking in olfactory bulb glomeruli. Nat. Neurosci. 5, 1194-1202. doi: 10.1038/nn953

Shao, Z., Puche, A. C., Kiyokage, E., Szabo, G., and Shipley, M. T. (2009). Two GABAergic intraglomerular circuits differentially regulate tonic and phasic presynaptic inhibition of olfactory nerve terminals. J. Neurophysiol. 101, 1988-2001. doi: 10.1152/jn.91116.2008

Shao, Z., Puche, A. C., Liu, S., and Shipley, M. T. (2012). Intraglomerular inhibition shapes the strength and temporal structure of glomerular output. $J$. Neurophysiol. 108, 782-793. doi: 10.1152/jn.00119.2012

Taniguchi, M., Yokoi, M., Shinohara, Y., Okutani, F., Murata, Y., Nakanishi, S., et al. (2013). Regulation of synaptic currents by mGluR2 at reciprocal synapses in the mouse accessory olfactory bulb. Eur. J. Neurosci. 37, 351-358. doi: 10.1111/ejn.12059

Tomita, N., Murata, M., Watanabe, H., Ichikawa, T., Washiyama, K., Kumanishi, T., et al. (2000). The effect of DCG-IV and L-CCG-I upon phencyclidine(PCP)induced locomotion and behavioral changes in mice. Ann N.Y. Acad. Sci. 914, 284-291. doi: 10.1111/j.1749-6632.2000.tb05203.x

Wang, S., Chen, X., Kurada, L., Huang, Z., and Lei, S. (2012). Activation of group II metabotropic glutamate receptors inhibits glutamatergic transmission in the rat entorhinal cortex via reduction of glutamate release probability. Cere. Cortex 22, 584-594. doi: 10.1093/cercor/bhr131

Watanabe, D., and Nakanishi, S. (2003). mGluR2 postsynaptically senses granule cell inputs at Golgi cell synapses. Neuron 39, 821-829. doi: 10.1016/S0896-6273(03)00530-0

Yuan, Q., and Knöpfel, T. (2006). Olfactory nerve stimulation-evoked mGluR1 slow potentials, oscillations, and calcium signaling in mouse olfactory bulb mitral cells. J. Neurophysiol. 95, 3097-3104. doi: 10.1152/jn.00001.2006

Zak, J. D., Whitesell, J. D., and Schoppa, N. E. (2015). Metabotropic glutamate receptors promote disinhibition of olfactory bulb glomeruli that scales with input strength. J. Neurophysiol. 113, 1907-1920. doi: 10.1152/jn.00222.2014

Zhou, F. W., Dong, H. W., and Ennis, M. (2016). Activation of $\beta$ Noradrenergic receptors enhances rhythmic bursting in mouse olfactory bulb external tufted cells. J. Neurophysiol. 116, 2606-2614. doi: 10.1152/jn.00034.2016

Conflict of Interest Statement: The authors declare that the research was conducted in the absence of any commercial or financial relationships that could be construed as a potential conflict of interest.

Copyright (c) 2018 Dong and Ennis. This is an open-access article distributed under the terms of the Creative Commons Attribution License (CC BY). The use, distribution or reproduction in other forums is permitted, provided the original author(s) or licensor are credited and that the original publication in this journal is cited, in accordance with accepted academic practice. No use, distribution or reproduction is permitted which does not comply with these terms. 